\title{
PRESJEK STANJA COVID-19 PANDEMIJE U HERCEGOVAČKO-NERETVANSKOJ ŽUPANIJI
}

\author{
Ivana Čović1 ${ }^{2}$, Marija Šantić ${ }^{1}$, Dino Peco ${ }^{2}$, Ana Bakula ${ }^{1}$ \\ ${ }^{1}$ Sveučilište u Mostaru, Fakultet zdravstvenih studija, 88000 Mostar, Bosna i Hercegovina \\ ${ }^{2}$ Zavod za javno zdravstvo Hercegovačko-neretvanske županije/kantona, 88000 Mostar, Bosna i Hercegovina
}

\section{SAŽETAK}

Uvod: Hercegovačko-neretvanska županija ima 216. 970 stanovnika i sastoji se od devet općina. Prvi slučaj zaraze korona virusom u Hercegovačko-neretvanskoj županiji zabilježen je 17. ožujka 2020. godine.

Cilj: Prikazati epidemiološku situaciju u navedenoj županiji od samog početka pandemije do početka mjeseca listopada. Materijali i metode: Podaci koji su korišteni obrađivani su u Zavodu za javno zdravstvo HNŽ/K i uzeti su sa platforme Zavoda za javno zdravstvo Federacije BiH, odnosno Covid-19. ba baze podataka. Informacije o pacijentima koji su pozitivni na COVID-19 potvrđeni su rt-PCR testom u Zavodu za mikrobiologiju i molekularnu dijagnostiku Sveučilišne kliničke bolnice Mostar.

Rezultati: Od 20155 obrađenih uzoraka njih 2917 je bilo pozitivno na virus. Zabilježeno je 37 smrtnih ishoda. Najveći broj oboljelih zabilježen je tijekom mjeseca rujna. U promatranom razdoblju uočeno je da više oboljelih čine žene, mada je razlika u nekoliko oboljelih osoba.

Zaključak: Uz poštivanje svih smjernica, epidemioloških mjera i preporuka kao županija možemo poboljšati trenutnu nepovoljnu situaciju te drastično smanjiti širenje virusa i broj oboljelih. Samim tim i broj hospitaliziranih, te na koncu i broj neželjenih smrtnih ishoda.

Ključne riječi: Covid-19; pandemija; Hercegovačko-neretvanska županija

Osoba za razmjenu informacija:

Ivana Čović, magistar sanitarnog inženjerstva

Email: ivana.covic@fzs.sum.ba 


\section{UVOD}

Do prije manje od dva desetljeća, svi poznati ljudski koronavirusi (CoV) uzrokovali su tako blage bolesti da nisu stimulirali daljnja napredna istraživanja CoV-a. 2002. i narednih godina scenarij se dramatično promijenio pojavom novih patogenijihCoV-a(1). 31. prosinca 2019. SZO (Svjetska zdravstvena organizacija) je obaviještena o slučajevima upale pluća nepoznatog uzroka u gradu Wuhan u Kini. Kineske su vlasti 7. siječnja 2020. utvrdile da je uzrok novi koronavirus koji je privremeno nazvan "2019-nCoV"(2). Nova pandemija koronavirusne bolesti 2019 (COVID-19) uzrokovana teškim akutnim respiratornim sindromom koronavirusom 2 (SARS-CoV-2) još uvijek napreduje i zabilježena je u više od 210 zemalja i teritorija širom svijeta(3)the first cases of COVID- 19 were detected on March 5, 2020 in the entity of the Republic of Srpska and on March 9, 2020 in the entity of the Federation of Bosnia and Herzegovina. By May 16, 2020, more than 2,200 COVID-19 cases had been recorded in both entities, with a mortality rate of $5.8 \%$ (131 of 2,231 cases. Širenje bolesti u Europi prvenstveno je uzrokovano kapljičnim prijenosom s čovjeka na čovjeka. Osim prijenosa s bolesnih ljudi, virus se prenosi i s asimptomatskih bolesnika. Razdoblje inkubacije iznosi do 14 dana nakon izlaganja uzročniku, $s$ prosječnom inkubacijom od četiri do pet dana(4). Nebrojeno puta se naglašavalo kako bi posebnu pozornost i napore trebalo dati na zaštiti ili smanjenju prijenosa u osjetljivoj populaciji, uključujući kronične bolesnike, imunokompromitirane osobe, djecu, zdravstvene djelatnike i osobe starije životne dobi. Za kontrolu trenutne epidemije potrebne su opsežne mjere za smanjenje prijenosa COVID-19 od osobe do osobe. Posebnu pozornost i napore treba uložiti na zaštiti ili smanjenju prijenosa u osjetljivoj populaciji, uključujući starije, imunokompromirirane osobe, osobe sa kroničnim bolestima i zdravstvene djelatnike (5). Iako znanost, posebice biomedicinsku i zdravstvenu, promatramo kao isključivo međunarodnu, ova pandemija je pokazala kako pojedine zemlje daju različit doprinos u zaštiti svojih građana. Pojedine države su se posebno istakle kada je u pitanju povjerenje u znanstvenike (6). Hercegovačko-neretvanska županija ima 216. 970 stanovni- ka i sastoji se od devet općina (Čapljina, Čitluk, Mostar, Jablanica, Konjic, Neum, Prozor/ Rama, Ravno i Stolac)(7). Prvi slučaj zaraze korona virusom u Hercegovačko-neretvanskoj županiji zabilježen je 17. ožujka 2020. godine(8).

Cilj ovoga rada je prikazati epidemiološku situaciju u navedenoj županiji od samog početka pandemije do početka mjeseca listopada. U obzir će biti uzeta svaka općina pojedinačno, te će se na taj način jasno vidjeti broj oboljelih u odnosu na broj stanovnika.

\section{MATERIJALI I METODE}

Rad prikazuje kretanje i širenje COVID-19 u Hercegovačko-neretvanskoj županiji od početka epidemije u Bosni i Hercegovini i Hercegovačko-neretvanskoj županiji konkretno, dakle od 17. 03. 2020 pa sve do 01. 10. 2020 što čini prvih 6 mjeseci prisustva SARS-CoV2 virusa u Bosni i Hercegovini (BiH) iHercegovačko-neretvanskoj županiji. Podaci koji su korišteni obrađivani su u Zavodu za javno zdravstvo Hercegovačko-neretvanske županije/kantona (HNŽ/K). Svi podaci korišteni za ovu studiju uzeti su sa platforme Zavoda za javno zdravstvo Federacije $\mathrm{BiH}$, odnosno covid-19. ba baze podataka. Informacije o pacijentima koji su pozitivni na COVID-19 potvrđeni su rt-PCR testom u Zavodu za mikrobiologiju i molekularnu dijagnostiku Sveučilišne kliničke bolnice Mostar (SKB).

\section{REZULTATI}

U Hercegovačko-neretvanskoj županiji od 17.03. do 01. 10. 2020. ukupno je testirano 20. 155 uzoraka. Svaka općina, sa pripadajućim Domom zdravlja testira stanovništvo kod kojeg se javila sumnja, tj. simptomi koji prethode ovom virusnom oboljenju. Testovi se obrađuju u Zavodu za mikrobiologiju i molekularnu dijagnostiku SKB Mostar. Od 20. 155 obrađenih uzoraka njih 2917 je bilo pozitivno na virus. Zabilježeno je 37 smrtnih ishoda od toga 24 pacijenta su bila na respiratoru, dok 13 pacijenata nije bilo na mehaničkoj ventilaciji pluća. Pacijenti su hospitalizirani na infektivnom odjelu SKB Mostar. Najveći broj testiranih pacijenata je sa područja općine Mostar zbog najvećeg broja stanovnika u cijeloj županiji. 


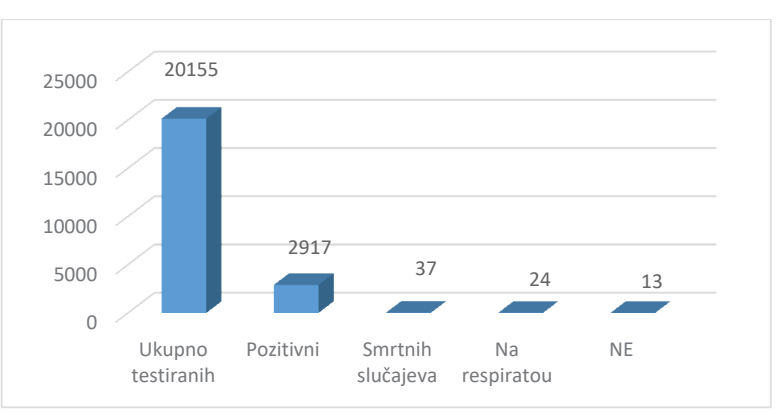

Slika 1. Kretanja broja oboljelih i broja umrlih od Covid-19 na području HNŽ u periodu17. 03. do 01. 10. 2020.

Od početka pojave pandemije u Hercegovačko-neretvanskoj županiji (17. 03. 2020. ) kroz nastavak mjeseca ožujka i kroz travanj vidimo porast broja oboljelih. Nagli porast vidljiv jenaručito kroz travanj. Kroz mjesec svibanj vidimo pad broja oboljelih sve do polovice lipnja. Pad broja oboljelih je rezultat epidemioloških mjera koje su bile provedene kroz prvi val pandemije. Krizni stožer Hercegovačko-neretvanske županije uveo je niz mjera koje su rezultirale poboljšanjem epidemiološke situacije u županiji. Neke od mjera bile su policijski sat, ograničene mjere kretanja te zabrane kretanja stanovništva između županija, Nošenje zaštitnih maski i rukavica, te pridržavanje propisane udaljenosti. Postupno smanjenje mjera dovelo je do ponovnog porasta broja oboljelih, koje kroz iduće mjesece, počevši od lipnja pa sve do listopada bilježi osjetan porast oboljelih. Poseban naglasak na mjesec rujan gdje je broj oboljelih uvelike povećan na nivou cijele županije.

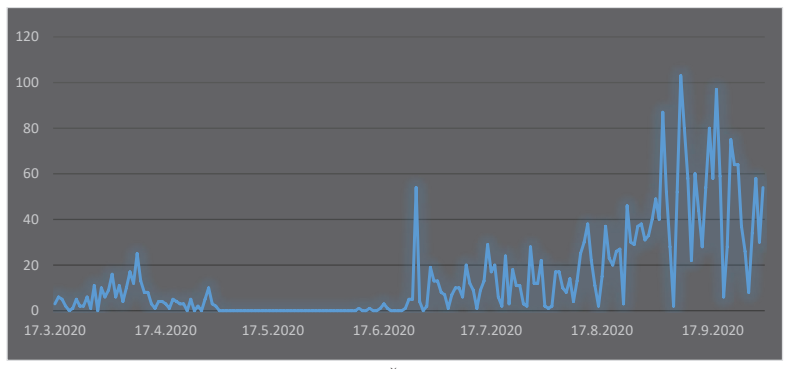

Slika 2. Prikaz broja oboljelih na području HNŽ u vremenskom periodu od 17. 03. do 01. 10. 2020.

Od ukupnog broja pozitivnih (2917) 1476 su žene, dok je 1441 muškarac. U promatranom razdoblju uočeno je da više oboljelih čine žene, mada je razlika u nekoliko oboljelih osoba. Možemo reći da trenutna, uočena razlika nije statistički značajna. Gledajuću po spolu, razlika pozitivnih je minimal- na te ovisi od mjeseca do mjeseca. Ukupno gledano više oboljelih osoba je ženskog spola, iako muškarci nisu u velikom zaostatku.

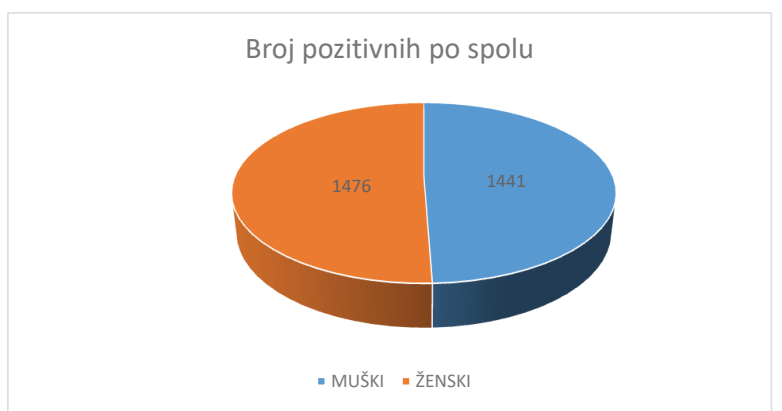

Slika 3. Prikaz broja pozitivnih osoba po spolu u HNŽ

Ukupan broj testiranih uzoraka varirao je svakodnevno od općine do općine, ovisno o epidemiološkoj situaciji u općinama, te angažiranosti lokalnih Domova zdravlja. Najviše uzoraka je testirano u Mostaru, u Domu zdravlja Mostar i Domu zdravlja Stari grad Mostar, njih 13380 od ukupno 20155, obzirom da je Mostar najveća i stanovništom najpokrivenija općina. Najmanje uzoraka je testirano u Općini Ravno obzirom na najmanji broj stanovnika. Također, najveći broj pozitivnih je sa područja Općine Mostar, njih 1770 od ukupno 2917 što je isto tako očekivano obzirom na broj testova, populaciju i broj stanovnika na $\mathrm{m}^{2}$. Tu također prednjače i sve druge općine sa mnogo manjom populacijom osim Jablanice, Neuma i Ravnog. Ukupna incidenca na 100000 stanovnika u svim općinama posebno je poprilično visoka, kao i cjelokupna incidenca za cijelu županiju. Na nivou županije incidenca iznosi 1344, 4, dok je incidenca u Općini Mostar 1682, 5 kao najveće općine. Međutim manje općine bilježe značajno veće incidence poput Općine Čitluk čija je incidenca bila čak 1967, 2.

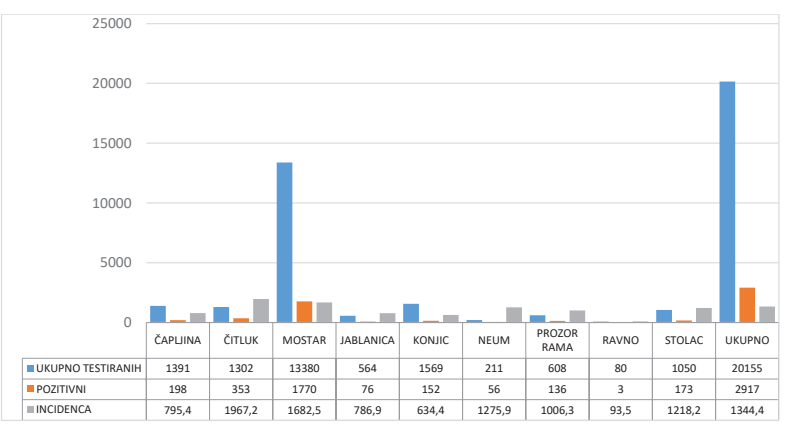

Slika 4. Prikaz broja oboljelih po općinama HNŽ u periodu od 17. 03. 2020. do 01. 10. 2020. 


\section{RASPRAVA}

Pacijenti s teškom i fatalnom bolešću imali su značajno povećan broj bijelih krvnih zrnaca (WBC) i smanjen broj limfocita i trombocita u usporedbi s ne-teškim bolestima i onima koji su preživjeli. Biomarkeri upale, ozljede srca i mišića, funkcije jetre i bubrega te mjere koagulacije također su značajno povišeni u bolesnika s teškim i fatalnim COVID-19. Interleukini 6 (IL-6) i 10 (IL-10) i serumski feritin bili su snažni diskriminator za ozbiljnu bolest. Stoga je identificirano nekoliko biomarkera koji mogu potencijalno pomoći u modelima stratifikacije rizika za predviđanje teškog i fatalnog COVID-19 (9). U Francuskoj je ova velika zdravstvena kriza hitno pokrenula restrukturiranje i reorganizaciju pružanja zdravstvenih usluga za podršku hitnim službama, jedinicama intenzivne medicinske skrbi i jedinicama za trajnu njegu. Zdravstveni radnici mobilizirali su sve svoje resurse kako bi pružili hitnu pomoć u općoj klimi neizvjesnosti. Sada se javljaju zabrinutosti zbog mentalnog zdravlja, psihološke prilagodbe i oporavka zdravstvenih radnika koji liječe i njeguju pacijente s COVID-19(10)this large-scale health crisis urgently triggered the restructuring and reorganization of health service delivery to support emergency services, medical intensive care units and continuing care units. Health professionals mobilized all their resources to provide emergency aid in a general climate of uncertainty. Concerns about the mental health, psychological adjustment, and recovery of health care workers treating and caring for patients with COVID-19 are now arising. The goal of the present article is to provide up-to-date information on potential mental health risks associated with exposure of health professionals to the COVID-19 pandemic.|nMETHODS: Authors performed a narrative review identifying relevant results in the scientific and medical literature considering previous epidemics of 2003 (SARS-CoV-1.

Pokazalo se da COVID-19 ima brži i širi prijenos, očitu obiteljsku aglomeraciju i veći morbiditet $\mathrm{i}$ smrtnost u odnosu na SARS. Prijenos probavnog trakta ne može se zanemariti, a vertikalni prijenos majke i djeteta je sumnjiv. Sugerira se da tradicionalne javne mjere poduzete s SARS-om možda neće biti dovoljne za suzbijanje pandemije COVID-19.
Međunarodna suradnja i razmjena resursa informacija mogu pomoći u smanjenju veličine izbijanja i smanjenju globalnih smrtnih slučajeva. Iako postoji mnogo sličnosti između SARS-a i COVID-19 od epidemiologije do kliničkih karakteristika, one također pokazuju razlike(11)both SARS-CoV and SARS-CoV-2, first appeared in China. They have certain biological, epidemiological and pathological similarities. To date, research has shown that their genes exhibit $79 \%$ of identical sequences and the receptor-binding domain structure is also very similar. There has been extensive research performed on SARS; however, the understanding of the pathophysiological impact of coronavirus disease 2019 (COVID-19. Izvješteno je da se teške komplikacije javljaju u 33\% bolesnika s COVID-19 i uključuju akutni respiratorni distres sindrom, akutno zatajenje bubrega, akutnu respiratornu ozljedu, septički šok i tešku upalu pluća. Trenutno ne postoji specifično liječenje ili odobrenocjepivo protiv COVID-19, a mnoga klinička ispitivanja trenutno istražuju potencijalne lijekove za liječenje COVID-19(12). Price-Haywoodi suradnici su utvrdili da crna rasa nije povezana $\mathrm{s}$ većom smrtnošću u bolnici od bijele rase(13). Ključna razlika između COVID-19 i sezonske upale pluća povezane s gripom je potencijalna težina bolesti čak i kod mladih odraslih osoba bez komorbiditeta (14)disease seriousness, impact. Procijenjeno je da je srednje razdoblje inkubacije 3-6 dana (raspon 1, 3-11, 3 dana). Trajanje od pojave simptoma do dispneje iznosilo je 5-6 dana(15)2019, Wuhan, China, has experienced an outbreak of coronavirus disease 2019 (COVID-19. Za uznapredovalubolest koja zahtijeva hospitalizaciju u prosjeku se javlja 7-8 dana od pojave simptoma. Pacijenti se u početku mogu činiti relativno stabilnima, ali često se brzo pogoršavaju s teškom hipoksijom(16). Težina bolesti i razvoj ARDS-a (akutni respiratorni distres sindrom) povezani su sa starijom dobi i osnovnim medicinskim stanjima. Smrtnost je neovisno povezana sa starijom dobi, većina je imala tešku bolest $\mathrm{i}$ doživjele komplikacije poput ARDS-a, akutne ozljede bubrega i sepse. Nadalje, pokazalo se da je vjerojatnije da će bolesnici s kardiovaskularnim bolestima razviti ozbiljne simptome. Za usporedbu, čini se da većina djece ima blagu 
bolest (17). Rizik za ozbiljne bolesti i smrt u slučajevima COVID-19 povećava se s godinama i prisutnošću komorbidnih zdravstvenih stanja. Da bi se stopa smrtnosti svela na najmanju moguću mjeru, pametno je odmah prepoznati simptome i na odgovarajući način primijeniti tretmane. Iako nije utvrđeno izlječenje, u tijeku su višestruka klinička ispitivanja kako bi se utvrdila najoptimalnija strategija. Upravljanje pacijentima s karcinomom u ovim je okolnostima prilično izazovno, s obzirom na njihov ranjivi status i agresivnu prirodu njihove osnovne bolesti (18). Studije su pokazale da ovaj virus uzrokuje lošije ishode i veću smrtnost kod starijih odraslih osoba i onih s popratnim bolestima kao što su hipertenzija, kardiovaskularne bolesti, dijabetes, kronična bolest dišnog sustava i kronična bolest bubrega. Značajan postotak starijih američkih odraslih osoba ima ove bolesti, što ih dovodi u veći rizik od zaraze (19). Na osnovu naših nalaza, strah i simptomi depresije u općoj populaciji Bosne i Hercegovine tijekom izbijanja COVID-19 bili su prisutni kod 18, 06\% (strah) i $28,39 \%$ (depresija) ispitanika i statistički je povezan s dob, spol, zanimanje, životni okoliš i mogu predstavljati sekundarni problem ustanka povezan s izbijanjem COVID-19. Od 1201 ispitanika, 217 (18, $0 \%)$ je prijavilo da osjeća strah, a $341(28,4 \%)$ da je imalo simptome depresije tijekom izbijanja COVID-19. Prosječna dob ispitanika bila je 30, $57 \pm 11$, 26 (20). S trenutne točke gledišta, čini se da bi u preživjelih od COVID-19, u sljedećim godinama i desetljećima, upalni sistemski proces i / ili upalni proces mozga mogli pokrenuti dugoročne mehanizme koji općenito dovode do povećanja neuroloških i neurodegenerativnih poremećaja. Psihosocijalne posljedice kao i posljedice na mentalno zdravlje također su značajne, kako za opću populaciju, tako i posebno za zdravstvene radnike svih profila (21)and then later spread rapidly to the rest of the world. On December 31, 2019, the World Health Organization (WHO. Tijekom pandemije COVID-19 sve su psihijatrijske službe u $\mathrm{BiH}$ funkcionirale u smanjenom opsegu. Svi pacijenti koji su zatražili pomoć adekvatno su liječeni u izravnoj bolničkoj ili ambulantnoj zaštiti mentalnog zdravlja ili na mreži, unatoč tome što telepsihijatrijske usluge nisu prepoznate $\mathrm{u}$ zdravstvenom sustavu u BiH(22)like any other pan- demic, has imposed an unprecedented threat to physical and mental health to all nations, worldwide. There is no enough evidence in the literature in this area. The present study has been done to explore the organization of psychiatric services in Bosnia and Herzegovina (BH. Nalazi studije pokazuju da je $\mathrm{u}$ razdoblju pandemije 2020. godine $\mathrm{u}$ Zapadnohercegovačkoj županijipotvrđeno ukupno 78 slučajeva zaraze. Od ukupnog broja zaraženih, $55,1 \%$ su žene, a 44, 9\% muškarci. Od zaražene populacije, 16, $7 \%$ je hospitalizirano. Praćenjem bolesti COVID-19 zaključujemo kako su bile zastupljene sve manifestacije bolesti, od asimptomatske, preko blage respiratorne do najteže kliničke slike sa smrtnim ishodima. Stopa smrtnosti u u Zapadnohercegovačkoj županiji iznosi 5, 1\% (23). Učestalo pranje ruku, izbjegavanje gužve i kontakta s bolesnim ljudima te čišćenje i dezinfekcija površina koje se često dodiruju mogu pomoći u prevenciji infekcija koronavirusom glavni su prijedlog stručnjaka SZO-a u trenutnim smjernicama, artefaktima pohranjenim na web mjestu (24) previously known as 2019 Novel Coronavirus (2019nCoV. U vrijeme kada se pandemija COVID-19 bliži vrhuncu, osim problema s liječenjem bolesti i njege kritično bolesnih pacijenata, postoje i drugi jednako važni problemi, poput organizacije odgovora na izbijanje epidemije, pružanja zdravstvene zaštite, nedostatka bolničkog osoblja, poremećaja u opskrbnim lancima osobne zaštitne opreme i zaštite zdravstvenih radnika(25)China initially and in a short time crossed the European borders. After mitigating the epidemic in China, Italy became one of the most COVID-19 affected countries worldwide. International travelers are important sources of infectious diseases and a possible source of epidemic. Due to its political, geographic, and cultural similarities, Italy is one of the main economic partners of Southeast European (SEE. Stopa hospitalizacije bila je 14, 0\% (790/5646) u Federaciji Bosne i Hercegovine (FBH) i 6, 2\% (267/4299) u Republici Srpskoj (RS). Stopa smrtnosti iznosila je 2, 2\% (122/5646) u FBH i 3, 6\% u RS (155/4299). Nakon što su vlasti ukinule obavezna ograničenja u karanteni, osnovni broj reprodukcije povećao se s 1,1320 . svibnja, na 1, 7231 . svibnja. Izbijanje se odnosi na oba entiteta, Federaciju Bosne i Hercegovine i Republiku Srpsku, a izra- 
ženije je u onima u dobi od 20 do 44 godine. Važno je razviti komunikacijski i hitni plan za izbijanje SARS-CoV-2 u BiH, uključujući mehanizme koji omogućavaju trajno obavještavanje i ažuriranje na nacionalnoj razini (26). Novi dokazi iz Kine sugeriraju da je koronavirusna bolest 2019. (COVID-19) smrtonosnija za zaražene muškarce od žena, a stopa smrtnosti od 2, 8\% zabilježena je kod kineskih muškaraca naspram 1, 7\% kod žena. Nadalje, podaci razvrstani prema spolu za COVID-19 u nekoliko europskih zemalja pokazuju sličan broj slučajeva među spolovima, ali teže ishode kod starijih muškaraca. Fatalnost je najveća u muškaraca s već postojećim kardiovaskularnim stanjima (27). U Sjedinjenim Državama, gdje je ispitivanje bilo prioritet za osobe sa simptomatskom bolešću, stope dijagnoze bile su slične u muškaraca i žena, ali muškarci su imali 1,5 puta veću smrtnost(28). Trenutno je zabilježena pristranost muškaraca u smrtnosti od COVID-19 u većini zemalja koje su pružile podatke razvrstane prema spolu. Podaci koji se pojavljuju pokazuju povoljnije ishode za odrasle ženke koje žive $\mathrm{u}$ zajednici u dobnim slojevima i nude neposrednu priliku za komparativne biološke eksperimente kako bi se definirale značajke patogeneze COVID-19 i pridruženi imunološki odgovor (29). Trenutna literatura ne podržava pušenje kao predisponirajući čimbenik kod muškaraca ili bilo koje podskupine za infekciju SARS-CoV-2(30). Objašnjeno je kako spol može utjecati na angiotenzin pretvarajući enzim-2 (ACE2), to je ključna komponenta za patogenezu COVID-19 i sažeo je rodne razlike u imunološkim odgovorima i kako su spolni hormoni uključeni u imunološke procese. Nadalje, istražuju se dostupni podaci o utjecaju spolnih hormona na imunološke funkcije slučajeva COVID-19(31). Međunarodno je poznato da se relativno mali broj slučajeva viđa kod djece, a općenito su slučajevi benigniji nego kod odraslih. Rizik od smrti raste kako starite. Smrtnost u kineskoj seriji studija iznosi $<0,5 \%$ u bolesnika mlađih od 50 godina, $2 \%$ (50-59 godina), 4\% (60-69 godina), $8 \%$ (70-79 godina) i $16 \%$ (> 80 godine). U Španjolskoj u vrijeme pisanja ovog članka smrtnost je $67 \%$ kod pacijenata starijih od 80 godina, $20 \%$ kod onih u dobi između 70 i 79 godina i $8 \%$ između 60 i 69 godina. Važno je napomenuti da, ako je identifikacija slučajeva bila univerzalna za cijelu populaciju, ove brojke mogu se znatno razlikovati (32).

\section{ZAKLJUČAK}

Uslijed pandemije COVID-19 zdravstveni sustav diljem svijeta je preopterećen. U Hercegovačko-neretvanskoj županiji trenutna epidemiološka situacija je izrazito nepovoljna. Uzimajući u obzir kapacitet bolnice i osoblja i sa druge strane broj oboljelih koji je iz dana u dan u naglom porastu. Na području cijele županije najveći broj testiranih, samim tim i oboljelih osoba je sa područja Mostara, obzirom da je Mostar najveća i stanovništvom najpokrivenija općina. Dnevni broj novooboljelih svakodnevno doseže nove rekorde unutar24 sata. Brojke su u svakom slučaju zabrinjavajuće i upućuju na dodatan oprez. Ukupna incidenca na 100000 stanovnika u svim općinama posebno je poprilično visoka, kao i cjelokupna incidenca za cijelu županiju. Gledajuću po spolu, razlika pozitivnih je minimalna te ovisi od mjeseca do mjeseca. Uloga svakog pojedinca u ovom slučaju je velika. Uz poštivanje svih smjernica, epidemioloških mjera i preporuka kao županija možemo poboljšati trenutnu nepovoljnu situaciju te drastično smanjiti broj oboljelih. Samim tim i broj hospitaliziranih, te na koncu i broj neželjenih smrtnih ishoda.

\section{LITERATURA}

1. Contini C, Caselli E, Martini F, Maritati M, Torreggiani E, Seraceni S, et al. COVID-19 Is a Multifaceted Challenging Pandemic Which Needs Urgent Public Health Interventions. Microorganisms. 2020 Aug 12; 8(8).

2. About the virus [Internet]. [cited 2020 Oct 25]. Available from: https: //www. euro. who. int/en/health-topics/health-emergencies/coronavirus-covid-19/novel-coronavirus-2019-ncov

3. Arapović J, Skočibušić S. The first two months of the COVID-19 pandemic in Bosnia and Herzegovina: Single-center experience. Bosn J Basic Med Sci. 2020 Aug 3; 20(3): 396-400.

4. Skitarelić N, Dželalija B, Skitarelić N. Covid-19 pandemija: kratki pregled dosadaš- 
njih spoznaja. Medica Jadertina. 2020 Apr 9; 50(1): 5-8.

5. Vasilj I, Ljevak I. EPIDEMIOLOŠKE KARAKTERISTIKE COVID-A 19. Zdr Glas. 2020 May 29; 6(1): 9-18.

6. Šimić J, Tomić V. LOKALNA ZNANSTVENA INFRASTRUKTURA U KONTEKSTU ZAŠTITE OD PANDEMIJE COVID-19. Zdr Glas. 2020 May 29; 6(1): 19-24.

7. HERCEGOVAČKO-NERETVANSKI KANTON U BROJKAMA. In Sarajevo: Federalni zavod za statistiku; 2020. Available from: http: //fzs. ba/wp-content/uploads/2020/06/ HNK_2020.pdf

8. COVID-19 [Internet]. ZZJZ FBiH. [cited 2020 Oct 25]. Available from: https: //www. zzjzfbih. ba/covid-19/

9. Henry BM, de Oliveira MHS, Benoit S, Plebani M, Lippi G. Hematologic, biochemical and immune biomarker abnormalities associated with severe illness and mortality in coronavirus disease 2019 (COVID-19): a meta-analysis. Clin Chem Lab Med. 2020 25; 58(7): 1021-8.

10. El-Hage W, Hingray $C$, Lemogne $C$, Yrondi A, Brunault P, Bienvenu T, et al. [Health professionals facing the coronavirus disease 2019 (COVID-19) pandemic: What are the mental health risks?]. L'Encephale. 2020 Jun; 46(3S): S73-80.

11. Zhou M-Y, Xie X-L, Peng Y-G, Wu M-J, Deng $\mathrm{X}-\mathrm{Z}, \mathrm{Wu} \mathrm{Y}$, et al. From SARS to COVID-19: What we have learned about children infected with COVID-19. Int J Infect Dis IJID Off Publ Int Soc Infect Dis. 2020 Jul; 96: 710-4.

12. Al-Quteimat OM, Amer AM. The Impact of the COVID-19 Pandemic on Cancer Patients. Am J Clin Oncol. 2020; 43(6): 452-5.

13. Price-Haywood EG, Burton J, Fort D, Seoane L. Hospitalization and Mortality among Black Patients and White Patients with Covid-19. N Engl J Med. 2020 25; 382(26): 2534-43.

14. Tolksdorf K, Buda S, Schuler E, Wieler LH, Haas W. Influenza-associated pneumonia as reference to assess seriousness of coronavirus disease (COVID-19). Euro Surveill Bull Eur Sur Mal Transm Eur Commun Dis Bull. 2020; 25(11).
15. Zhou F, Yu T, Du R, Fan G, Liu Y, Liu Z, et al. Clinical course and risk factors for mortality of adult inpatients with COVID-19 in Wuhan, China: a retrospective cohort study. Lancet Lond Engl. 2020 28; 395(10229): 1054-62.

16. Wang D, Hu B, Hu C, Zhu F, Liu X, Zhang J, et al. Clinical Characteristics of 138 Hospitalized Patients With 2019 Novel Coronavirus-Infected Pneumonia in Wuhan, China. JAMA. 2020 17; 323(11): 1061-9.

17. Cevik M, Bamford CGG, Ho A. COVID-19 pandemic-a focused review for clinicians. Clin Microbiol Infect. 2020 Jul; 26(7): 842-7.

18. Gosain R, Abdou Y, Singh A, Rana N, Puzanov I, Ernstoff MS. COVID-19 and Cancer: a Comprehensive Review. Curr Oncol Rep. 2020 08; 22(5): 53.

19. Shahid Z, Kalayanamitra R, McClafferty B, Kepko D, Ramgobin D, Patel R, et al. COVID-19 and Older Adults: What We Know. J Am Geriatr Soc. 2020; 68(5): 926-9.

20. Šljivo A, Kačamaković M, Quraishi I, Džubur Kulenović A. FEAR AND DEPRESSION AMONG RESIDENTS OF BOSNIA AND HERZEGOVINA DURING COVID-19 OUTBREAK - INTERNET SURVEY. Psychiatr Danub [Internet]. 2020 Aug 13 [cited 2020 Nov 7]; 32(2): 266-72. Available from: https: //hrcak. srce. hr/242371

21. Sinanović O, Muftić M, Sinanović S. COVID-19 Pandemia: Neuropsychiatric Comorbidity and Consequences. Psychiatr Danub. 2020; 32(2): 236-44.

22. Pajevic I, Hasanović M, Avdibegović E, Džubur-Kulenović A, Burgić-Radmanović M, Babić D, et al. Organization of mental healthcare in Bosnia and Herzegovina during coronavirus disease 2019 pandemic. Indian J Psychiatry [Internet]. 2020 Sep 1 [cited 2020 Nov 7]; 62(9): 479. Available from: https: //www. indianjpsychiatry. org/article. asp?issn $=0019-5545$; year $=2020$; volume $=62$; issue $=9$; spage $=479$; epage $=491$; aulast $=$ Pajevic; type $=0$

23. Vasilj I, Herceg K, Čović I, Šantić M, Curlin M, Ljevak I, et al. Determinants of the CO- 
VID-19 Pandemic in the West Herzegovina Canton. Psychiatr Danub. 2020 Sep; 32(Suppl 2): 221-5.

24. Gerc V, Masic I, Salihefendic N, Zildzic M. Cardiovascular Diseases (CVDs) in COVID-19 Pandemic Era. Mater Socio-Medica. 2020 Jun; 32(2): 158-64.

25. Puca E, Čivljak R, Arapović J, Popescu C, Christova I, Raka L, et al. Short epidemiological overview of the current situation on COVID-19 pandemic in Southeast European (SEE) countries. J Infect Dev Ctries. 2020 May 31; 14(5): 433-7.

26. Hukic M, Ponjavic M, Tahirovic E, Karabegovic A, Ferhatbegovic E, Travar M, et al. SARS$\mathrm{CoV}-2$ virus outbreak and the emergency public health measures in Bosnia and Herzegovina: January - July, 2020. Bosn J Basic Med Sci. 2020 Oct 21;

27. Gebhard C, Regitz-Zagrosek V, Neuhauser HK, Morgan R, Klein SL. Impact of sex and gender on COVID-19 outcomes in Europe. Biol Sex Differ. 2020 25; 11(1): 29.

28. COVID-19: Data Main - NYC Health [Internet]. [cited 2020 Oct 26]. Available from: https: //www1. nyc. gov/site/doh/ covid/covid-19-data. page

29. Scully EP, Haverfield J, Ursin RL, Tannenbaum C, Klein SL. Considering how biological sex impacts immune responses and COVID-19 outcomes. Nat Rev Immunol. 2020; 20(7): 442-7.

30. Cai H. Sex difference and smoking predisposition in patients with COVID-19. Lancet Respir Med. 2020; 8(4): e20.

31. Maleki Dana P, Sadoughi F, Hallajzadeh J, Asemi Z, Mansournia MA, Yousefi B, et al. An Insight into the Sex Differences in COVID-19 Patients: What are the Possible Causes? Prehospital Disaster Med. 2020 Aug; 35(4): 438-41.

32. Ortiz-Prado E, Simbaña-Rivera K, Gómez- Barreno L, Rubio-Neira M, Guaman LP, Kyriakidis NC, et al. Clinical, molecular, and epidemiological characterization of the SARS-CoV-2 virus and the Coronavirus Disease 2019 (COVID-19), a comprehensive literature review. Diagn Microbiol Infect Dis. 2020 Sep; 98(1): 115094. 


\title{
OVERVIEW OF THE COVID-19 PANDEMIC IN THE HERZEGOVINA-NERETVA CANTON
}

\author{
Ivana Čovićn ${ }^{1,2}$, Marija Šantić ${ }^{1}$, Dino Peco ${ }^{2}$, Ana Bakula ${ }^{1}$ \\ ${ }^{1}$ Faculty of Health Studies University of Mostar, 88000 Mostar, Bosnia and Herzegovina \\ ${ }^{2}$ Institute for Public Health HNK/Ž, 88000 Mostar, Bosnia and Herzegovina
}

\begin{abstract}
Introduction: The Herzegovina-Neretva Canton has 216, 970 inhabitants and is made up of nine municipalities. The first case of coronavirus infection in the Herzegovina-Neretva Cantonwas recorded on March 17, 2020.

Objective: Provide an overview of the epidemiological situation in the canton from the start of the pandemic until the beginning of October.

Subjects and methods: The data were analyzed at the Institute for Public Helath of the Herzegovina-Neretva Canton and were downloaded from platform of the Institute for Public Health of the Federation of Bosnia and Herzegovina or the Covid-19. ba database. Information on patients who tested positive for Covid-19 was confirmed by a RT-PCR test at the Department of Microbiology and Molecular Diagnostics of the University Clinical Hospital Mostar.

Results: Out of the 20155 processed samples, 2917 tested positive for the virus. There were 37 deaths reported. The highest number of cases was recorded during the month of September. In the period considered, it was observed that the incidence of the virus was greater in women, although the difference was in several patients.

Conclusion: Following guidelines, epidemiological measures and recommendations, the canton can improve the current unfavorable situation and unfavorable situation and drastically reduce the spread of the virus and the number of patients, and therefore, the number of hospitalized, and finally the number of deaths.
\end{abstract}

Key words: Covid-19; pandemic; Herzegovina-Neretva Canton

Correspondence:

Ivana Čović, Master of sanitary engineering

E-mail: ivana.covic@fzs. sum.ba 